Присяжнюк О. М., кандидат історичних наук, доцент кафбедри всесвітньої історії та методологї̈ науки Південноукраїнського національного педагогічного університету ілені К. Д. Ушинського

\title{
ОСЯГНЕННЯ НАЦІОНАЛЬНОГО МИНУЛОГО ТА ОФОРМЛЕННЯ ОСНОВ ОХОРОНИ ПАМ'ЯТОК У ФРАНЦІЇ
}

\begin{abstract}
Анотація. Безпосереднє становлення державної системи охорони пам'яток у Франції було результатом революцій 1789 та 1830 рр. У другій чверті XIX століття відбулося зростання інтересу до національної історії, національного минулого, що було зумовлене не лише природним розвитком науки, а й загальними політичними та соціально-економічними умовами. Власне інституціоналізація збереження стародавніх пам'ятників здійснилася в період Липневої монархії, який часто визначається як «момент Гізо», за ім'ям французького історика та політичного діяча Франсуа Гізо, який обіймав пост міністра внутрішніх справ з серпня до листопада 1830 року та міністра народної освіти з листопада 1832 до квітня 1837 рр. Протягом декількох років, з 1830 по 1837, за його ініціативою були створені основні інститути цієї централізованої державної системи: Генеральна інспекція історичних пам'яток (1830), Товариство історії Франції (1833), Комітет історичних та наукових робіт (1834), Комісія історичних пам'яток (1837). Вони стали організаційним втіленням політики, що проводилась королем Луї-Філіпом і Франсуа Гізо. Свій прихід до влади Ф. Гізо ознаменував проведенням реформ, які проголошував перш за все як історик. Його хвилював пошук основ для національної єдності, узаконення третього стану, вимоги, що висуваються новою національної історією. Ним була розроблена та втілена програма історичного виховання французького суспільства.
\end{abstract}

У Франції прагнення відновити національну єдність, пошук національної свідомості та ідентичності здійснювався на основі публічної політики. Можна сказати, що уряд та державні установи багато в чому не тільки ініціювали цю діяльність, але й здійснювали керівництво та контроль за ії здійсненням. Були створені спеціальні державні установи для зібрання, вивчення та збереження пам'яток вітчизняної історії, як писемних, так і матеріальних. Уряд країни розумів, що вирішити поставлені завдання самостійно неможливо, потрібна допомога наукових товариств, які почали активно розвиватися в той час. Вже у 1830-х роках у Франції склалася розвинена мережа наукових товариств, що займалися вивченням стародавніх пам'яток. Завершенням тривалого процесу формування законодавчої бази стало прийняття першого загального закону 30 березня 1887 р., положення якого згодом було розроблено «Законом про пам'ятки історії» від 31 грудня 1913 року.

Ключові слова: національна історія, національне минуле, музеєзнавство, історична пам'ятка, охорона пам'яток, законодавча база, спадщина.

Постановка проблеми. Європейський класицизм, корені якого сягають в культуру передреволюційної Франції, в першій чверті XIX століття вичерпав свої творчі можливості. 3 ідеології революції він перетворився на ідеологію наполеонівської імперії і разом з нею був розчавлений рішеннями Віденського конгресу. У другій чверті XIX століття пережита Францією та французами криза системи цінностей, пов'язана 3 французькою революцією і подальшими подіями, поступово долалася непростим шляхом - від ідеалізації античного минулого до осягнення минулого національного [8, с. 68-69]. У цей час набув значного поширення романтизм, що був реакцією на класицизм та всю добу Просвітництва. Важливою рисою романтизму була так звана «пассеїська рефлексія», що виражалася в захопленні старовиною, іiі поетизації, інтересі до народного життя і народної словесності, яка тим самим спонукала до глибокого вивчення свого національної минулого. Крім цього, інтерес до «своєї» історії та «своїх» пам'ятників, здебільшого релігійних, організація їх охорони і розвиток реставрації як самостійного архітектурного руху були визначені внутрішньополітичними проблемами Франції, пов'язаними з радикальною зміною соціально-політичного вигляду самого суспільства $[12$, c. $4-5]$.

Аналіз останніх досліджень і публікацій. Джерельну базі статті склали дві фундаментальні праці Ежена Віолле-ле-Дюка, які містять його роздуми про архітектуру, принципи реставрації середньовічних пам'яток, міркування про велич середньовічної готики [3; 4]. Також нами був використаний Новий французький закон про історичні пам'ятники 1913 року, що складається 3 шести глав та 39 статей [11], який став базовим законом та основою Кодексу національного надбання.

«Вступ до археологіі» Сергія Олександровича Жебелева став першою, нині забутою працею, що включала в себе систематичний виклад історії археологічної науки з позицій антикознавця. Книга виросла на базі лекційного курсу, який автор читав на історико-філологічному факультеті Санкт-Петербурзького університету до Першої світової війни [5]. У статті Н.С. Ніколаєвої наводиться короткий порівняльний аналіз створення державної системи охорони пам'яток у Франції та Росії в другій чверті XIX століття. Розглядаються чинники, що впливають на формування ставлення до пам'ятників минулого як на рівні державної ідеології, так і суспільства зокрема [10]. Докладний огляд художньо-археологічних відкриттів кінця XIX - початку XX ст. здійснений у грунтовній праці Адольфа Михаєліса - видатного вченого-археолога, професора Страсбурзького університету [9]. В узагальненому огляді музеїв Франції І. Кукліновою розглянуто історію виникнення i розвитку приватних колекцій та музеїв протягом XIV - кінця ХІХ століть [7].

Мета статті - проаналізувати процес осягнення національного минулого та оформлення основ охорони пам'яток у Франції протягом XIX століття. 
Виклад основного матеріалу дослідження. Ще у 1810 році міністром внутрішніх справ графом де Монталіве був розісланий циркуляр, згідно з яким префектам пропонувалося зібрати інформацію про замки, абатства (монастирі) та гробниці, що існують на території їх департаментів. У розробці циркуляру брав участь граф Олександр де Лаборд, автор твору «Пам’ятники Франції, класифіковані хронологічно та розглянуті відносно історичних фактів і вивчення мистецтв», перший том якого вийшов в світ у $1816 \mathrm{p}$.

Наступна епоха реставрації (1815-1830), на жаль, демонструє приклади грубого вандалізму і непростимої байдужості уряду, тому в 1830 році Шарль де Монталамбер нарікав на те, що за 15 років існування королівства в кожному департаменті Франції зруйновано більше пам'ятників, ніж за весь революційний та імператорський періоди [2, с. 107].

Уряд не перешкоджав тому, щоб стародавні приватні будівлі руйнувалися або перетворювалися на фабрики чи майстерні. Навпаки, уряд використовував пам'ятники церковного та світського зодчества для військових цілей (Мон-Сен-Мішель, папський палац в Авіньйоні). Таким людям, як Віктор Гюго, Проспер Меріме, Шарль де Монталамбер, Жан-Батист Лассо, Ежен Емманюель Віолле-ле-Дюк, з'єднаними зусиллями з вченими товариствами та французьким духовенством вдалося викликати не тільки серед освічених людей, а й в широких верствах французького населення жвавий інтерес до пам'ятників минулих років [2, с. 108]. Роман Віктора Гюго «Собор Паризької богоматері» (1830) пролунав гімном на славу середньовічної архітектури та закликом до збереження іiі спадщини. Предметом загальної уваги спочатку став виведений в романі собор. Надалі йшлося також не про спорудження нових будівель, а про реставрацію шедеврів французького середньовіччя, будь-то Сент-Мішель, Мон-Сен-Мішель, грандіозне абатство Везле, стародавні укріплення Каркассона або гірський замок Роктайад. До здійснення практично всіх реставраційних проектів доклав руку невтомний Ежен Віолле-ле-Дюк, який прагнув довести навіть недобудовані в середні віки споруди до краю завершеності.

У 1840 р. П. Меріме доручив Е. Віолле-ле-Дюку реставрувати церкву Мадлен у Везле, якій загрожувало завалення, тоді ж він був запрошений відновлювати каплицю Сен-Шапель у Парижі. У 1844 році разом з Жаном-Батистом Лассю він переміг у конкурсі на право реставрації собору Паризької богоматері. Ця робота тривала майже двадцять років (1845-1864) та була високо оцінена. У 1846 р. Віолле-ле-Дюк отримав посаду архітектора абатства Сен-Дені біля Парижа, де їм була, зокрема, переглянута атрибуція надгробків. Доля сприяла молодому архітектору, він відразу стикнувся з шедеврами i, практично не маючи серйозних конкурентів, виступив першовідкривачем нових тоді методів реставрації старовинних будівель. Ця робота стала справою всього його життя. У 1846 р. йому довіряють відтворення базиліки абатства Сен-Дені біля Парижа, а у 1849 р. - Ам'єнський собор. Далі будуть кріпосні стіни Каркассона, замки Пьєрфон, Кусі, церкви в Пуассі, Каркассоні, Семюрі, Лані, Шалоні-на-Марні, архієпископський палац в Нарбонні, ратуша в Сен-Антонені, ворота Сент-Андре в місті Отені. Якщо до цього додати розширення однієї старої та будівництво в різних містах трьох нових церков, зведення приватних будинків в Парижі, виготовлення малюнків вітражів та меблів, то розмах звершень архітектора, з урахуванням того, що відтворення деяких будівель розтягувалося до 22-23 років, здається вражаючим, точніше сказати, неймовірним. Однак при цьому Віолле-ле-Дюк знаходив час писати книги та статті з історії архітектури, використовуючи матеріали музеїв, архівів, бібліотек, своїх подорожей і спостережень [6, с. 8-9].

Загалом за своїми художніми поглядами Віолле-ле-Дюк примикав до напряму французького романтизму. Він високо цінував готичну архітектуру, проте не нижче оцінював споруди античного світу. Споруди епохи середньовіччя притягали архітектора, тому що в них він бачив виразне функціональне призначення. Знаходячи опору своїм пошукам в середньовіччі, Віолле-ле-Дюк, однак, не ідеалізував старовину і засуджував механічне запозичення форм старої архітектури. «Вивчення минулого необхідно, - писав він, - але за умови, щоб з нього виводилися швидше принципи, а не форми» [3, с. 302]. Примирення науки та мистецтва, інженера та архітектора, союз і єдність мистецтва та архітектура, звільнена від впливу політики - такими були цілі, проголошені цим істинним реформатором та критиком XIX ст.

Підводячи підсумки своїм роздумам, Віолле-ле-Дюк проникливо писав у своїх «Бесідах з архітектури»: «Мистецтво має своє дитинство, що подає надії на блискучий розвиток в майбутньому; воно має і свою старість, яка завжди нагадує про те, чим воно було в минулому; істинно варварським воно стає тільки тоді, коли воно принижується, зраджуючи своїм принципам або перекручуючи їх <..> коли воно, не відображаючи більш звичаїв народу, стає зайвим, перетворюється на предмет цікавості або розкоші» [3, с. 412].

Справедливості заради відзначимо, що творчість Віолле-ле-Дюка, особливо методи реставрації, викликає суперечливі оцінки. Слід пояснити позицію самого архітектора, який відстоював принцип повного збереження об'єкта реставрації. «Реставрувати будівлю не означає підновляти iï, ремонтувати або перебудовувати, це значить - відновлювати її завершений стан, якого вона могла й не мати ніколи до теперішнього часу» [4, с. 118]. Ця теза передбачає кілька умов: по-перше, відновлення пам'ятника базується на попередньо проведених археологічних та інших дослідженнях; по-друге, слід забезпечити довговічність споруди; по-третє, використання будівлі в сучасних цілях можливо, якщо це не вимагає іiі спотворення; по-четверте, слід зберегти всі колишні зміни і перебудови, крім тих, що погіршують міцність будови.

Такий підхід до реставрації привів до того, що відтворені Е. Віолле-ле-Дюком споруди дійсно виглядали закінченими та досить однорідними. Надалі методичні установки архітектора були оскаржені - реставратори в ряді випадків відмовилися будь-що надавати старовинним спорудам «завершеного стану». Дійсно, не всі втрачені частини будівлі можна достовірно відновити. Експерти, однак, зійшлися на тому, що, незважаючи на зайві деталі та доповнення, серйозних концептуальних та археологічних помилок Віолле-ле-Дюк зміг уникнути.

Праці Віолле-ле-Дюка показові щодо його громадської позиції. Він виступав не тільки як фахівець, що подолав бар'єр між наукою і практикою, але й як патріот Франції та одночасно всієї Європи, захисник світової культурної спадщини. Якби не втручання Віолле-ле-Дюка, до теперішнього часу було б втрачено багато найцінніших пам'яток минулого.

Тобто, насамперед спираючись на громадську думку, зацікавлену у розвитку історії та мистецтва, французький уряд 
3 початку тридцятих років приймає цілий ряд заходів, спрямованих на охорону пам'яток.

Власне інституціоналізація збереження стародавніх пам'ятників здійснилася в період Липневої монархії, який часто визначається як «момент Гізо», за ім'ям французького історика та політичного діяча Франсуа Гізо, який обіймав пост міністра внутрішніх справ з серпня до листопада 1830 року та міністра народної освіти з листопада 1832 до квітень 1837 рр. Протягом декількох років, з 1830 по 1837, за його ініціативою були створені основні інститути цієї централізованої державної системи: Генеральна інспекція історичних пам'яток (1830), Товариство історії Франції (1833), Комітет історичних та наукових робіт (1834), Комісія історичних пам'яток (1837). Вони стали організаційним втіленням політики, що проводилась королем Луї-Філіпом і Франсуа Гізо.

Свій прихід до влади Ф. Гізо ознаменував проведенням реформ, які проголошував перш за все як історик. Иого хвилював пошук основ для національної єдності, узаконення третього стану, вимоги, що висуваються новою національної історією. Ним була розроблена та втілена програма історичного виховання французького суспільства. «Це серйозна хвороба нації, говорив Ф. Гізо, - нехтувати минулим і забути його» [12, с. 14]. Було логічно, що уряд 1830 року, так само як і уряд Першої імперії, шукав у повазі до минулого, в культі давньої Франції гарантії стабільності, які були відсутні під час їх встановлення. У минулому особливо виділялася епоха середньовіччя, коли «єдність суспільства грунтувалася на союзі монархії з третім станом» [1, с. 217]. Національному примиренню сприяв католицький рух. У поверненні до вірувань Ф. Гізо бачив користь для збереження соціального порядку та розглядав релігію як засіб, який розвіє моральні страждання нижчих класів. Саме релігійне відродження, розцінюючи готичний стиль як вираження католицької віри, більшою мірою, ніж романтизм, сприяло тріумфу середньовічної архітектури, яку стали активно вивчати та зберігати. Воно визначило не тільки будівництво великого числа нових церков в «неоготичному стилі», а й консервацію та реставрацію давніх, зруйнованих в роки Французької революції та наполеонівських воєн [1, с. 217].

Початком втілення в життя «програми історичного виховання» Ф. Гізо можна розглядати створення за його ініціативи в жовтні 1830 року посту генерального інспектора історичних пам'яток у структурі Міністерства внутрішніх справ. Першим генеральним інспектором історичних пам'яток був призначений політичний діяч, письменник та археолог Людовик Віте, який обіймав цю посаду до 1834 р. Змінив його Проспер Меріме, який очолював генеральну інспекцію історичних пам'яток з 1834 по 1860 pp. Функції, які повинен був виконувати генеральний інспектор, досить точно сформульовані в звіті Л. Віте по закінченню його першої службової поїздки на Північ Франції у 1831 р.: «Встановлювати існування і робити критичний опис усіх будівель королівства, які або за датою, або за характером їх архітектури, або за подіями, свідками яких вони були, заслуговують уваги археолога, художника, історика - така перша мета покладених на мене обов'язків. По-друге, я повинен піклуватися про збереження цих будівель, вказуючи уряду та місцевій владі способи попередження або зупинки їх руйнування〉 [10, с. 263].

Природно, що одна людина не в змозі була виконати ці завдання. Тому вже під час створення посади генерального інспектора Ф. Гізо ратував за створення в провінції місцевих громад по аналогії з Товариством антикварів Нормандії, які найбільш ефективно, на його думку, забезпечили б збереження пам'яток. У зв'язку з чим у французьких дослідженнях, присвячених історії пам'яткоохоронної діяльності, формування Служби історичних пам'яток Ф. Гізо розглядається як відповідь на ініціативу графа Арсіса де Комона, який у 1824 р. заснував Товариство антикварів Нормандії [1, с. 94].

Діяльність Товариства антикварів Нормандії зіграла істотну роль в організації аналогічних товариств та проведенні наукових засідань у французьких провінціях. У 1831 р. буде створено Товариство антикварів Моріні, у 1834 - Товариство антикварів Заходу, у 1836 - Товариство антикварів Пікардії. Створене у 1831 році Археологічне товариство півдня Франції буде вважати себе наступником Товариства антикварів Нормандіi. Перше наукове засідання відбулося в Кані у липні 1833 р., друге - в Пуатьє у 1834 р. У їх роботі взяло участь двісті осіб. Підсумком таких наукових засідань стане створення у 1839 р. Інституту провінцій [10, с. 263].

Успіх нормандського суспільства привів до думки про створення наукового товариства вже в національному масштабі. У липні 1834 було засновано Французьке археологічне товариство, спочатку зване Французьким товариством збереження та опису історичних пам'яток [1, с. 94]. Метою нового Товариства було вивчення пам'яток Франції, складання їх списку та запобігання їх руйнуванню або спотворенню невмілими реставраціями. 3 моменту свого заснування Товариство щорічно стало проводити археологічні конгреси в різних провінційних містах, звіти про які друкувалися в "Bulletin monumental", а з 1845 року стали випускатися окремим виданням. Так, у Франції була сформована потужна національна мережа наукових товариств.

Роком раніше, ніж створення Французького археологічного товариства, було створено Товариство історії Франції, одним із засновників якого був також Ф. Гізо, що займав тоді вже пост міністра народної освіти. У січні 1834 р. був прийнятий статут цього Товариства, почалися роботи з вивчення і публікації справжніх джерел, що належать до національної історії. У липні 1834 р. Ф. Гізо заснував Комітет історичних та наукових робіт, метою якого було вивчення й видання неопублікованих документів з історії Франції. У січні 1835 р. створено ще один комітет, який сприяв дослідженням та публікації невиданих документів з літератури, філософії, науки і мистецтва, що належать до загальної історії Франції - Комітет неопублікованих пам'яток літератури, філософії, науки і мистецтва, що розглядаються в зв'язку із загальною історією Франції [10, с. 263]. Цей Комітет об'єднав головних засновників Служби історичних пам'яток: В. Гюго, В. Кузена, Л. Віте, О. Лепрево, Ш. Ленормана, П. Меріме, А. Ленуара, А.-Н. Дідрона. У 1837 році наступник Ф. Гізо на посаді міністра народної освіти, Нарсіс-Ашіль де Сальванді, провів реорганізацію Комітету неопублікованих пам'яток, розділивши його на п'ять секцій відповідно до п'ятьох класів Інституту Франції. Одна 3 секцій отримала назву Комітет мистецтв та пам'ятників і перебувала під патронажем Академії витончених мистецтв. До завдань цього комітету входило складання списку пам'яток Франції, турбота про збереження пам'яток і надання допомоги в організації наукової роботи в провінції [10, с. 263].

В момент створення Комітету неопублікованих пам'яток Ф. Гізо звернувся до наукових товариств із закликом до спів- 
праці, обіцяючи надання з боку держави матеріальної допомоги, забезпечення обміну публікаціями і щорічне видання найбільш важливих наукових досліджень в національному журналі [10, с. 264]. У 1837 році в структурі Міністерства внутрішніх справ була створена Комісія історичних пам'яток, функції якої також полягали у виявленні та вивченні пам'ятників, складанні їх списку, забезпеченні їх охорони на основі спеціально виділених з боку держави дотацій, керівництві реставраційними роботами [7, с. 76].

3 моменту свого виникнення комісія спиралася на офіційно встановлену раніше мережу кореспондентів, що складалася з місцевих ерудитів або наукових товариств, які повинні були повідомляти про будівлі, які знаходяться під загрозою, або про проведення реставрацій. У дванадцяти департаментах ці функції виконували наукові товариства. Там, де їх не було, префекти створювали коміcii. На жаль, через десять років роль цих провінційних товариств і кореспондентів була зведена до мінімуму [10, с. 264]. У 1837 р., слідуючи традиції Першої імперії, була складена чергова анкета, що складалася з 39 питань, згідно з якою префекти повинні були повідомити про найбільш важливі пам'ятники і пам'ятники, які потребують термінових дій з їх збереження.

На основі їх відповідей та 3 їх допомогою були визначені перші грошові асигнування. У 1840 році Комісія історичних пам'яток опублікувала список пам' ятників. Так, з організацією Комісії історичних пам'яток завершилося формування державної системи охорони пам'яток, що відобразило задум Ф. Гізо, спрямований на інвентаризацію всіх документів, що мають відношення до духовної та моральної історії Франції - архівів, бібліотек, пам'яток та творів мистецтва.

Таким шляхом була закладена основа системи класифікаціï, на якій були побудовані французький та пізніші закони, що стосуються пам'ятників. Цілою низкою розпоряджень було встановлено, щоб знищення або зміна історичних споруд допускалося тільки 3 дозволу міністерства народної освіти. Однак через відсутність законних повноважень прийняті урядом заходи не завжди досягали своєї мети. Тільки від доброї волі власників та розсуду установ, незалежних від міністерства народної освіти, залежало, якою мірою дотримуватися його розпоряджень. Тому у 1875 році міністр народної освіти Анрі-Олександр Валлон виробив законопроект, який зосереджував всю турботу про пам'ятники в руках міністерства народної освіти і надавав міністерству необхідні повноваження. Тільки 30 березня 1887 року проект цей, після багатьох перипетій та різноманітних переробок, був прийнятий палатою депутатів. А розпорядження про заборону відчуження пам'яток, що міститься в статті 18 закону, було опубліковано лише 3 червня 1889 року. Загалом французький закон 30 березня 1897 року зобов'язаний своїм виникненням головним чином митцям і науковцям, а також вченим товариствам [2, с. 109].

Положення першого комплексного закону 30 березня 1887 року були розвинені наступним «Законом про історичні пам'ятники» від 31 грудня 1913 року. Важливою новацією цього закону було те, що він припускав централізований облік не тільки державних пам'ятників, але й тих культурних цінностей, які перебували в приватній власності. Також у цьому законі окремо характеризуються археологічні пам'ятники, хоча будь-яких спеціальних норм щодо археологічних розкопок ще немає [11].

Висновки. Формування державної системи охорони пам'яток у Франції стало наслідком революцій 1789 та 1830 рр.
У другій чверті XIX ст. відчувався підйом інтересу до національної історії, національного минулого, який був зумовлений не тільки природним розвитком науки, а й головним чином політичними та соціально-економічними умовами. У Франції прагнення до відновлення національної єдності, пошук національної свідомості здійснювалися на основі державної політики. Можна сказати, що уряд і державні установи багато в чому не тільки ініціювали цю діяльність, а й здійснювали керівництво та контроль над іiі виконанням. Були створені спеціальні державні установи, спрямовані на зібрання, вивчення та збереження пам'яток національної історії.

Уряд країни розумів, що самостійно поставлені завдання не вирішити, необхідна допомога наукових товариств, які стали активно розвиватися в цей час. У Франції вже в 1830-ті роки склалася розвинена мережа наукових товариств, що займалися вивченням пам'яток старовини. Слід також відзначити значення місцевої адміністрації, яка сприяла не тільки вивченню старожитностей, але й їх збереженню, знаходячи джерела фінансування цих робіт. Як загальну проблему можна назвати відсутність фахівців на місцях, що багато в чому ускладнювало виконання поставлених завдань і насамперед створення зводу пам'яток, який розглядався як основна міра їх збереження.

Логічним завершенням тривалого процесу формування основ законодавчої охорони пам'яток стало прийняття першого комплексного закону 30 березня 1887 року, положення якого були згодом розвинені «Законом про історичні пам’ятники» від 31 грудня 1913 року.

Лimepamypa:
1. Базен Ж. История истории искусств: От Вазари до наших дней. Москва : Прогресс-Культура, 1994. 528 с.

2. Виланд К.А. Охрана памятников и родины в современных законодательствах. Известия Императорской Археологической Комиссии. Т. 20 (1906). С. 101-150.

3. Виолле-ле-Дюк Э.Э. Беседы об архитектуре. Москва : Изд-во Всесоюзной академии архитектуры. Т. 1. 1937. $472 \mathrm{c.}$

4. Виолле-ле-Дюк Э.Э. Энциклопедия готической архитектуры. Москва : ЭКСМО, Наше слово, 2012. 512 с.

5. Жебелёв С.А. Введение в археологию. Часть II. Теория и практика археологического знания. Петроград : Наука и школа, 1923. C. $80-81$.

6. Кирпичников А.Н. Виолле-ле-Дюк. Жизнь, деятельность, творчество. Виолле-ле-Дюк Э.Э. Жизнь и развлечения в средние века. Санкт-Петербург : Евразия, 2003. С. 7-14.

7. Куклинова И. А. Музеи Франции XIV-XIX веков. Санкт-Петербург : СПбГУКИ, 2001. 148 с.

8. Лебедев Г.С. История отечественной археологии. Санкт-Петербург : Изд-во СПбГУ, 1992. 464 с.

9. Михаэлис А. Художественно-Археологические открытия за 100 лет. Москва : Издание Императорского Московского Археологического Института Имени Императора Николая II, 1913 г. [2], II, IV, 403 с.

10. Николаева Н. С. Формирование государственной системы охраны памятников во второй четверти XIX века (сравнительный анализ: Франция и Россия). Известия Российского государственного педагогического университета им А. И. Герцена. 2008. Вып. 80. С. 261-270.

11. Новый французский закон об исторических памятниках (Утвержден 31 декабря 1913 г.). Известия императорской археологической комиссии. Санкт-Петербург, 1916. Вып. 60. С. 106-116.

12. Рыцарев К.В. Некоторые тенденции в западноевропейской архитектурной реставрации XIX века. Реставрация и архитектурная археология : Новые материаль и исследования. Москва, 1995. Вып. 2. С. 4-19. 
Prysiazhniuk O. Comprehension of the national past and design basics of monument protection in France

Summary. The direct formation of the state system for the protection of monuments in France was the result of the revolutions of 1789 and 1830 . In the second quarter of the XIX century there was a rise in interest in national history, the national past, which was due not only to the natural development of science, but also mainly to political and socio-economic conditions. The preservation of ancient monuments was institutionalized during the July monarchy, which is often defined as the "Guizot moment", named after the French historian and prominent politician Francois Guizot, who served as Minister of the Interior from August to November 1830 and Minister of Education from November 1832 to April 1837. For several years, from 1830 to 1837 , on his initiative, the main institutions of this centralized state system were created: General Inspectorate of Historical Monuments (1830), General in the history of France (1833), the Committee of historical and scientific works (1834), the Commission of historical monuments (1837). They were the organizational embodiment of the policies pursued by King Louis Philippe and François Guizot.
In France, the desire to restore national unity, the search for national consciousness was carried out on the basis of public policy. We can say that the government and state institutions in many ways not only initiated this activity, but also carried out leadership and control over its implementation. Special state institutions were created to collect, study and preserve monuments of national history, both written and tangible. The government of the country understood that it was impossible to solve the assigned tasks, the help of scientific societies, which began to develop actively at that time, was needed. In France already in the 1830s a developed network of scientific societies involved in the study of ancient monuments has developed. The completion of the long process of forming the legislative base was the adoption of the first comprehensive law on March 30, 1887, the provisions of which were subsequently developed by the "Law on Historical Monuments" of December 31, 1913.

Key words: national history, national past, museum studies, historical monument, monument protection, legislative base, heritage. 